\title{
EDUCATIONAL TECHNOLOGY
}

\section{Educational technology assets for marketing: Product, process, package}

\author{
Sue McNamara \\ Monash University
}

\begin{abstract}
Educational Technology is perhaps the one field in education which is readily equipped to deal with the challenges being given to Education in Australia today. A brief review of the concepts and components of Educational Technology highlights some of the positive responses which Educational technology can offer to the current dilemmas facing education.
\end{abstract}

The marketing of education is a most controversial topic in Australia today. Opponents of the idea of marketing cite the notion of education for all as a democratic right and contend that therefore it should be beyond the clutches of commercialisation. Proponents of the idea put forward the argument that if Australia is to survive in world economics and trade we must begin to view education and educational specialisations (such as educational technology) as marketable commodities. Both poles of the continua of debate interpret the profit of marketing in terms of monetary or economic gain.

Undoubtedly education costs, and the costs are continually increasing. As the technologies of instruction become increasingly sophisticated the monetary costs associated with operation, maintenance of hardware software, and courseware increase accordingly. It can be claimed though that the costs are offset by the functions they fulfil. For the purposes of this article however the costs, in economic terms are not the concerns under discussion. The economic concerns of marketing and the question of who pays is best left to those more conversant with financial issues. Whilst acknowledging the general association of marketing with financial gain and the importance of these considerations in the overall implementation of a marketing strategy for educational technology, this article focuses on an alternative basis for marketing, within a more ideological or sociological definition of profit and concept of the market place. 
Although some more pessimistic educationalists might say that conjecture of the ideal is the equivalent to fantasising, let us indulge our imaginations for a few moments and consider (what these same persons might classify as impossible) - the ideal. Under ideal conditions:

the marketing of educational technology is the provision or delivery of appropriate learning environments, facilities, opportunities and experiences which will equip learners with the skills and capabilities to live full and productive lives.

In sociological terms the profits of the marketing of educational technology lie in the ability of the human being to live and participate successfully in a continually changing society.

\section{What has educational technology got to offer the market place?}

On a somewhat more practical level the question might be asked as to what educational technology has to offer the marketplace and who are the potential clients of educational technology? Government and business have provided the jargon for describing the assets which educational technology can offer the market place. The current buzzwords of 'training' and 'package' reflect the concerns of both of these bodies with the emphasis on outputs or the products of specifically, systematically designed instructional processes and learning experiences.

The Australian Education Taskforce report (1985) suggested that if the potential of new technologies for education was to be realised professional development of educators was essential. The report identified areas such as evaluation, resource management, and the effects of technology as critical components of technology training and use in education. In the light of a discussion of the marketing of educational technology the report noted that there is an unmet demand for both short and long term training programs and materials to equip professionals, trainers, instructors and others with appropriate skills in dealing with the technologies of instruction. The implications of these concerns can be summarised in three terms which may be held as synonymous with the practices of educational technology: product, process and package. Who better to deal with 'systems' design and application to instruction than those equipped with the skills of Educational Technology?

Educational Technology has been defined as the design, application evaluation and development of systems, methods, and materials to improve the process of human learning (ASET definition). Under this umbrella term (ie, educational technology) lie the theoretical and practical base for the development of a marketable commodity. 
Within the field of educational technology are the components of:

- instructional design,

- information technology resources and management,

- systems and curriculum development,

- cognitive and information processing,

- media production,

- research and evaluation of instructional products and processes.

- human resources development and management

- training and management of training systems and facilities

- instructional research and learning research

\section{The educational technology product}

The product of Educational Technology might refer to any one of the numerous educational materials developed for instructional purposes. Systematic design is applied by educational technologists to the development of print, audio, still and motion visuals, computer instruction and any other technologies which might be applied to learning (Heinich, Molenda and Russell, 1982). These materials form an integral part of education and instruction from primary through to tertiary education including apprenticeship, industrial and commercial training.

With the questions of ownership and copyright uppermost in the minds of those responsible for the selection, development and distribution of instructional technology and materials, the role of educational technology in providing adequate and appropriate instructional materials is obvious. A large proportion of instructional materials used in Australia today is imported, yet Australia has the educational expertise and facilities to produce equivalent - and often superior - instructional materials, better suited to the Australian market than the work of our overseas counterparts and colleagues. Competitively the Australian Educational Technology product is an asset the market place can ill afford to underestimate.

Further the 'product' asset of Educational Technology is not merely concerned with the creation of singular goods. Rather it might refer to any one of the numerous projects undertaken by educational technologists and instructional design departments, within formal education (eg, the universities, institutes and TAFE colleges) and in private enterprise. Interactive videodisc products such as the Supertext - Superdisc (Steele, 1987), or computer software such as MicroEd (Bruce College of TAFE Muddle, 1987) illustrate the involvement of Educational Technology in the production of products requiring sophisticated organisational planning and execution. 
The objectivity of the systems approach, including needs assessment, task analysis, planned development, production and evaluation allows the application of educational technology to problems within and beyond the realms of institutionalised education. Awards such as the recent AFI award to the program Curriculum by Design: A Working Model (Box Hill TAFE/Hawthorn Institute of Education, 1987) bear testimony to the potential quality of products produced by educational technology specialists.

\section{The process}

The term product can be subject to broad interpretation and it is difficult to differentiate between product, process and package. For the purposes of discussion though the process is taken as referring to the skills of instructional design, materials and curriculum development, training coordination management and execution of evaluation of product and project, and in the delivery of instruction (Kemp, 1986). The responsibilities of the educational technologist vary from human resources development to staff training and the planning and implementation of new instructional technology systems on both small and large scales.

The process skills and experience of the 'how to' in instructional development are skills very much in demand in industry and commerce and in the education sector, particularly when closely related to the technologies of instruction. Private industry cannot afford the luxury of 'lagging behind' in new technological developments, nor can it afford to have employees ill equipped and unskilled in dealing with these developments. The design and training skills of Educational technology are assisting industry in meeting its needs. Examples of instructional design courses and educational technology skill development programs are often cited in the literature (eg, Martinez, 1986; Dick, 1987) and not all are within the framework of institutionalised education (eg, Semisch and Splaine, 1986). Many are not conducted in this country, but that is not to say that Australia does not have the capabilities to conduct them. Educational technology must continue to develop its skills and parallel this development in fostering the marketing of these skills in both private enterprise and formal education.

\section{The package}

A third area which might be seen as an asset of educational technology, and one applicable in the market place is that of the package. Governments are continually releasing to the media descriptions of their new 'packages' ranging from initiatives to deal with child poverty and smoking to plans for retirement and the unemployed. The educational technology package might consist of any number of products and 
processes, developed into a plan of action for training or instructional purposes. When traditionally the package was assumed to contain perhaps a slide-tape program, printed materials and associated video, the current package can be anything from a small scale one off production to a multi-million dollar training development agreement. Regardless of the size, the involvement of educational technology can be viewed as an asset to the success of the package.

\section{Future prospects}

The above discussion illustrates some potential educational technology assets for the market place. Having the asset however does not make it marketable. In order to be marketable some one must be interested in the proposition the vendor has to offer. Educational technology needs clients. Who would be interested in utilising educational technology? The preceding paragraphs have hinted at the viability of educational technology in industry and private enterprise and no doubt the trend towards the involvement of educational technology in this area will continue to strengthen as government purse strings tighten. But what of the traditional educational consumer - the educational institution. Has educational technology nothing to offer these clients in the coming future?

Although the present and future formal educational climate in Australia has been forecast as one of doom and gloom, the present belt-tightening and 'era of accountability' in institutionalised education should perhaps be viewed as timely resources for educational technology. The challenge for educational technology is to capitalise on these resources. Traditionally, media and technology expenditure have been among the first casualties in times of belt tightening. The present trend however appears to be towards an increased emphasis on technology. One might suggest that it is both in the best interests of, and the responsibility of educational technology to ensure that this trend does not become a bandwagon affair, but rather serves to improve the flexibility of, and quality of learning in Australia.

Increasingly economic and political pressures are being brought to bear on Education. Formal educational institutions are being encouraged to reassess their policies, priorities and directions. In the past eighteen months we have witnessed the reintroduction of tertiary fees in the form of 'administrative charges'. Slight increases in these fees are being implemented in 1988 with massive increases being predicted in the near future. Organisationally these same institutions are being confronted with decreasing student enrolments and a larger proportion of students opting for part-time or external mode studies. In an attempt to rationalise the educational structures, amalgamations and internal restructuring is occurring from the primary school level through to the institutional and ministerial or government departmental level. 
The privatisation of education is being seen not only in the growing number of primary and secondary students attending private schools with falling numbers in government schools, nor solely in the forthcoming private university, but also in the development of private companies devoted to the marketing of educational products, materials and training formally produced by institutionalised education. These trends are signalling the need for a general reassessment of institutionalised education and the development of alternative directions in the form of more flexible structures, frameworks and courses. Ultimately these changes are acting as a catalyst for the greater employment of the products, processes and packages of educational technology.

\section{Conclusion}

It is thus in every field of education and learning that educational technology has a role to play. Admittedly, that is a tall order. However in positive terms the diversity of areas, skills and forms of expertise which educational technology encompasses means that the somewhat bleak and austere future forecast by many for education, may not eventuate for educational technology in Australia.

Educational Technology has the opportunity to generate the products, processes and packages, required by both formal education and private enterprise. What better assets could the market place require than what educational technology has to offer?

\section{References}

Curriculum by design: A working model. (1987). Program produced by a joint designated grant: Box Hill College of TAFE/Hawthorn Institute of Education.

Dick, W. (1987). Instructional design and the curriculum development process. Educational Leadership, 44(4), 54-56.

Heinich, R., Molenda, M. and Russell, J. (1982). Instructional media and the new technologies of instruction. New York: John Wiley.

Kemp, J. (1986). Training for ID: Learning ID through the ID Process. Performance and Instruction, 25(2), 6-9.

Martinez, C. (1986). A Checklist for Course Evaluation. Performance and Instruction, 25(5), 12-19.

Muddle, N. (1987). The MicroEd Manual. Bruce College of TAFE.

Education and Technology. (1985). Report of the Australian Education Taskforce.

Semisch, C. and Splaine, J. (1986). The training and development function in industry: A case study. Media Management Journal, 5(2), 5-11. 
Steele, J. (1987). The Superdisc supertext project. Australian Journal of Educational Technology, 3(1), 45-56.

http:/ / www.ascilite.org.au/ajet/ajet3/steele.html

Author: Sue McNamara is a postgraduate student at Monash University where she is completing a doctorate in Educational Technology. Her address is Faculty of Education, Monash University, Clayton, Victoria 3168.

Please cite as: McNamara, S. (1987). Educational technology assets for marketing: Product, process, package. Australian Journal of Educational Technology, 3(2), 101-107.

http: / / www.ascilite.org.au/ajet/ajet3/mcnamara.html 